\title{
フライ調理における食品の状態の変化と油吸収 \\ Physical State Change of Food in Deep-Fat Frying and Oil Absorption Mechanism
}

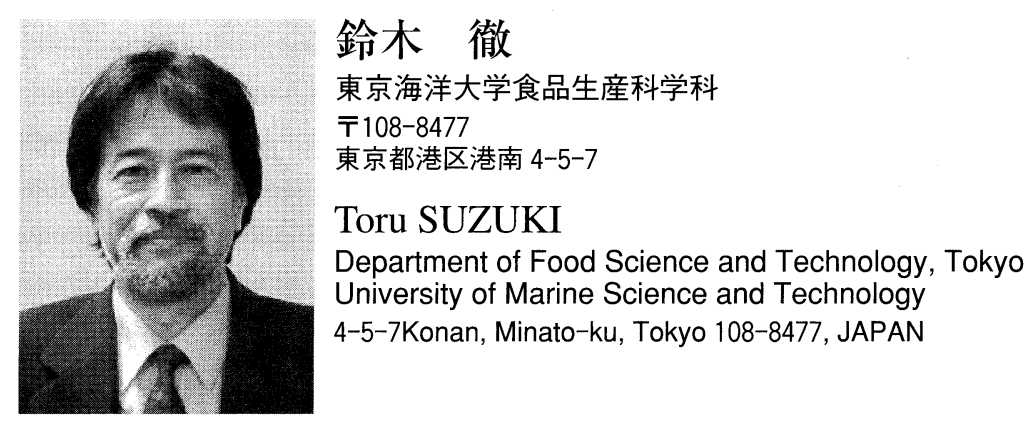

論文要旨：フライ調理は世界的にも主要な調理手法であり，各国で古くから利用されてきたが，一方で健 康問題，また資源・環境問題からフライ調理品に油脂吸収残存を少なくする努力が払われ，多くの研究が行 われてきた。近年，フライ調理中の食材に対する油吸収について注目すべき進歩が見られる。すなわちモデ ル系として小麦粉一水混合物を使った食品素材の状態図を利用しフライ過程での状態変化の経路を推察する ことで，水分含量によって多孔質構造生成が異なり，結果として油吸収，水分蒸発メカニズムに影響を及ほ すことが明らかにされた。すなわち油吸収はフライ過程では蒸気圧に拮抗する小さな細孔内の毛管力による 吸収によって起こり，ポストフライ過程では蒸気の凝縮減圧による吸収によって生じる。よって初期水分含 量の低い食品への油吸収は主としてフライ過程での油吸収が支配的であり, 水分含量の高いバッター状の食 品では発達した複雑な表面に付着した油のポストフライ過程での吸収が支配的であることが明らかにされた。

\begin{abstract}
Although deep-fat frying is a common unit operation that is extensively used for food preparation in both household and commercial cooking, in recent year, the existing of health conscious about the high consumption of fat from fried food is extremely concerned. So that the researches in the reduction of oil absorption in fried food have been widely conducted. As a result, by using a state diagram of food, there was a noticeable progress for understanding concerning to the mechanism of oil uptake on deep-fat frying process. It was found that the development of porosity inside food matrix due to water vaporization influences on oil absorption in frying and post-frying process. From study using wheat flour-water mixture model food with varying initial moisture content, it can be said that the oil absorption in the sample containing the initial moisture content less than $60 \%$ was governs by the capillary action in frying process, while that in the sample containing initial moisture content more than $60 \%$ was governs by vapor condensation pressure due to cooling in post-frying period. And also, it was revealed that the effect of initial moisture content on the alteration of surface roughness of fried sample, subsequently affects on oil absorption in post-frying process.
\end{abstract}

Key words: deep fat frying, Oil absorption mechanism wheat flour-water mixture model food

\section{1 緒 言}

フライ調理は世界的にも主要な調理手法であり，各国 で古くから利用されてきた。近年では, 調理冷凍食品産 業, ファーストフード産業などにおいても大量に生産さ

連絡者：鈴木 徹

E-mail : toru@kaiyodai.ac.jp
れる機会が多くなった一方で健康問題，また資源・環境 問題からフライ調理品に油脂吸収残存を少なくする努力 が払われている 分の蒸発乾燥が急速に進行するプロセスであるが，その 間，デンプン糊化，タンパク質の変性が相互に影響を及 ぼし合いながら進む非常に複雑な過程であり，そのメカ ニズムに関する科学的理解は十分とは言えない。 
近年では，一般的にフライ調理における油吸収はフラ イ過程とポストフライ過程の両者において起こると考え られている2)。フライ過程とは油中に食品が浸漬されてい る間の過程であり，その間に食品中の水分は蒸発し多孔 質構造を形成する。これが続き水分蒸発が少なくなり蒸 気圧が低くなると毛管力によって油が多孔質に進入する ようになる。一方で，ポストフライ過程（これは油から 食品が取り出された後の過程を意味する）において，油 から取り上げられた直後は食品の温度は高く多孔質内は 高い蒸気圧を保っている。しかし，食品の温度が低くな るに従って, 多孔質内部の蒸気は凝縮し多孔質内部は負 圧に転じる。この時, 食品表面に付着していた油は多孔 質内部に吸引されることになる。こういった知見は主に ポテトフライに関する研究から得られている。欧米では ポテトフライを食すことが多く，ポテトを対象としたフ ライ調理研究が多いためである。また，衣を付けたフラ イ食品も比較的多く，バッ夕ーに関する研究も見られ る。しかし，それらは断片的であり，フライ調理過程を 体系的に捉えようとした試みは無かった。筆者の研究グ ループでは小麦粉をベースとして水分含量を広く変化さ せたモデル食品を用いてフライ調理過程における物理化 学的状態変化と多孔質構造の形成過程のメカニズム, さ らにはそれらの及ぼす油の吸収度について研究を行って きた。本記事ではそれらについて解説する。ちなみに， 少ない水分含量の場合はドウ，多くの水分を含むとき バッターと呼ばれているが，基本的構成成分は同じであ るにもかかわらず，各々のフライ調理過程が異なる。そ れらを統一的に理解しようとした試みでもある。

\section{2 フライ過程における多孔質形成過程}

フライ食品の多孔質構造は油吸収に影響を及ぼすばか りでなく，テクスチャーにとっても重要な因子でもあ る。その食品の多孔質構造の形成にはフライ調理中の食 品高分子のガラス転移など物理的状態変化が影響を及ぼ すと考えられている ${ }^{3,4)}$ 。これは，フライ調理以外でも同 様であり，小麦粉＋水の混合物であるモデル食品をエク ストルーダー内で高圧高温処理した場合，グルテンの 2 次構造やデンプンなどの結晶領域は解け溶融し流動性を 持つようになる。その状態から常温大気圧下に押し出さ れると水分が急激に蒸発し発泡し，かつ水分含量が急激 に減少する。これによって，デンプンなど食品高分子は ガラス状態となり分子運動性が低くなる。また小麦粉+ 水の混合食品のエクストルーダーによる多孔質化過程に おいて, 内部食材の温度がガラス転移温度より低い場 合，多孔質構造の発達が抑えられることが知られてい $3^{5)}$ 。フライ調理食品の多孔質形成もエクストルーダー 処理の場合と類似のメカニズムが働くと考えられる。す なわち, 高温油に浸漬された食品内の水分の蒸発膨張と 並行して食品成分の物理化学的状態の変化が進行し, 工 クストルーダー処理と同様に乾燥したクリスピーな多孔 質構造が作り出されると考えられる。

こういった食品加工, 貯蔵時に起こる種々の変化を理 解するために食品材料の状態図が必要とされる。この状 態図は，食品素材のガラス転移温度，またタンパク質変 性温度やデンプンの糊化温度が水分によって変化する様 子を示す図である6)。しかしながら，フライ調理過程に 対して状態図を利用した研究例は非常に少なかった。

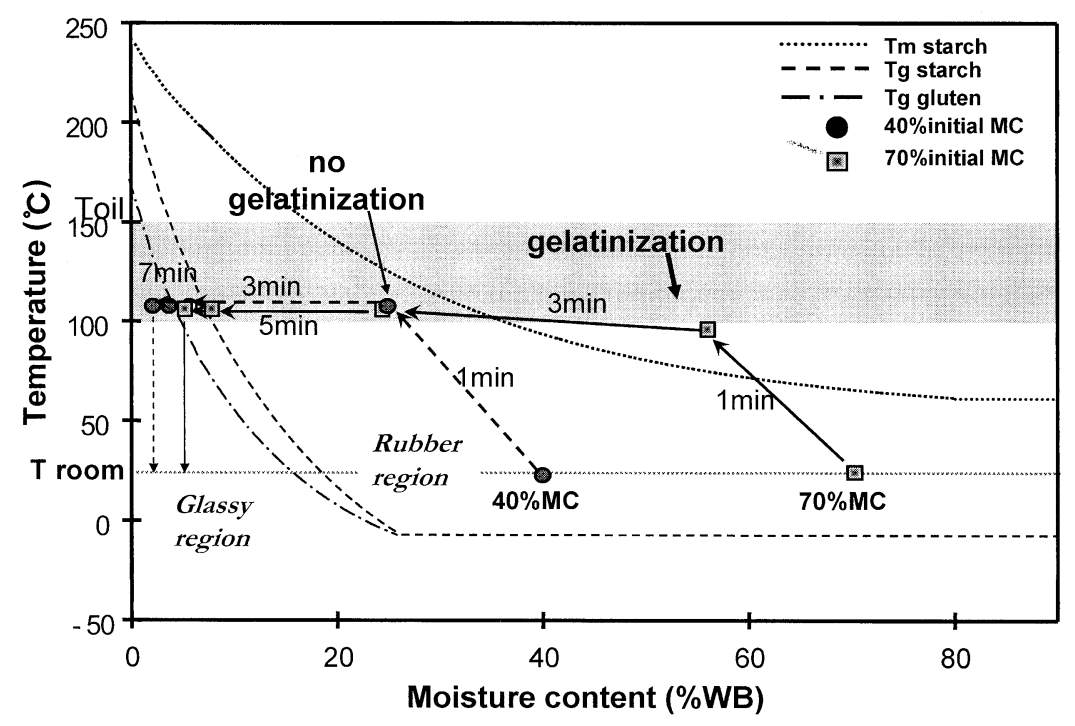

Fig. 1 The Pathway of Frying of Wheat Flour-Water Model with 40 and 70\% Initial Moisture Content. 
Vitrac 等( ${ }^{7)}$ フライ調理食品の温度と残存水分含量から おおよその状態図を仮定し，フライ調理過程における素 材の化学的変化の予測を試みたが，状態図そのものの

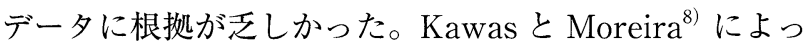
てフライ調理トルティージャ（メキシコ料理のひとつ で，とうもろこしの粉をこねたもの）の「ガラス転移温 度一水分曲線」などが報告されているが，加工工程中に おける状態変化との対応については考察されなかった。 こういった状況の下 Thanatuksorn と筆者等 ${ }^{9)}$ は小麦 粉一水の混合物，すなわちバッターやドウのフライ調理 過程を理解するため，初期水分含量 40\%と60\%に調製 した試料を薄い円盤状に成型し $150^{\circ} \mathrm{C}$ の食用油中でフラ イ調理した際の試料の水分含量と試料中心温度の時間的 変化を追って調べた。さらにそのデー夕（水分，温度） を，以下に述べる小麦粉の状態図上にプロットし，試料 のたどる経路を明らかにした。これを Fig. 1 に示す。 ここで用いた小麦粉の状態図はあらかじめ熱分析（DSC） によって調べられたもので，図中には低水分域で比較的 高温にあるデンプンのガラス転移曲線と低い転移温度を 示すグルテンのガラス転移曲線が示されている。また, 同時にデンプンの糊化温度の水分依存性を示す曲線も描 かれている。二つの成分混合物が別のガラス転移温度を 示すことは，議論の余地があるが ${ }^{10)}$ Kalichevsky と Blanshard $^{11)}$ も類似の結果を報告しており概ね正しいと 考えられる。これらガラス転移曲線の上の領域はゴム状 な柔らかい状態であり，ガラス転移より下部の領域はガ ラス状態にありクリスピーなテクスチャーを示す。ま た，デンプンの糊化曲線を超えるとデンプン粒の糊化が 起こる。Fig. 1 によれば，初期水分が 40\%（ドウに相 当）の試料では水分が少なく試料の温度上昇にもかかわ らず，デンプンの糊化曲線に十分到達せず，さらに水分 が蒸発減少する。よってデンプンは十分な糊状態になれ ないため蒸気で生じた細孔は大きくなれず微小な細孔が 多数できる。最終的に, 高温で水分蒸発減少し, 室温に 戻ったときにグルテン，デンプンのガラス転移曲線の下 の領域に達して，クリスピーな状態となり，クッキー状 のサクサクした食感のプロダクトが得られる。これに対 して，初期水分が $60 \%$ の試料（バッター状）では温度 上昇ともにデンプンの糊化曲線を十分超え試料内部のデ ンプン粒は崩壊し，流動性のある連続相になると考えら れる。またそこで発生した蒸気の泡は膨張を許されるた め大きな孔をもつ多孔質構造が発達する。さらに加熱状 態で水分が除かれ乾燥領域に入りグルテン，デンプンの 高温状態でガラス転移温度，あるいはそれに近い領域に 到達しバッターは硬いガラス状態となる。そのため, 発 達した多孔質は形状が維持される。この状態を油から取
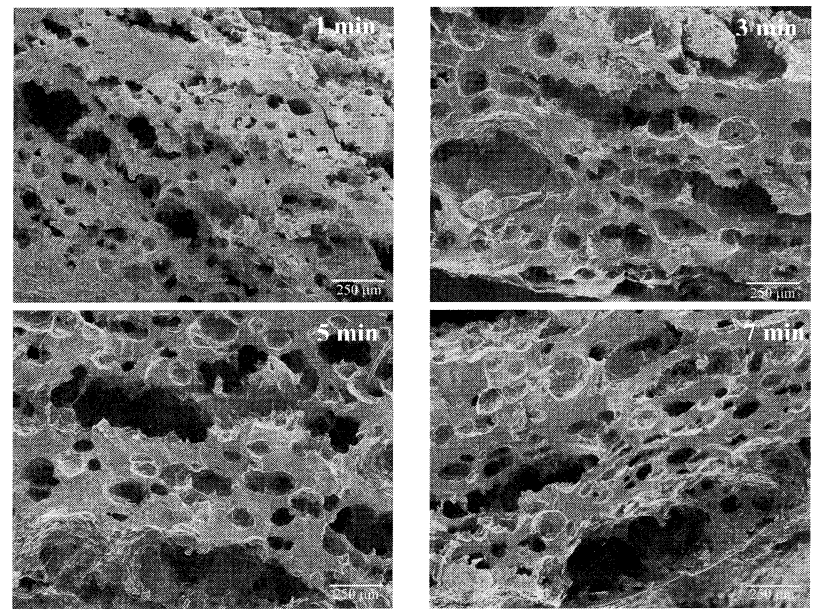

Fig. 2 SEM Photos of Fried Samples Containing 40\% Initial Moisture $(\mathrm{x} 60)$
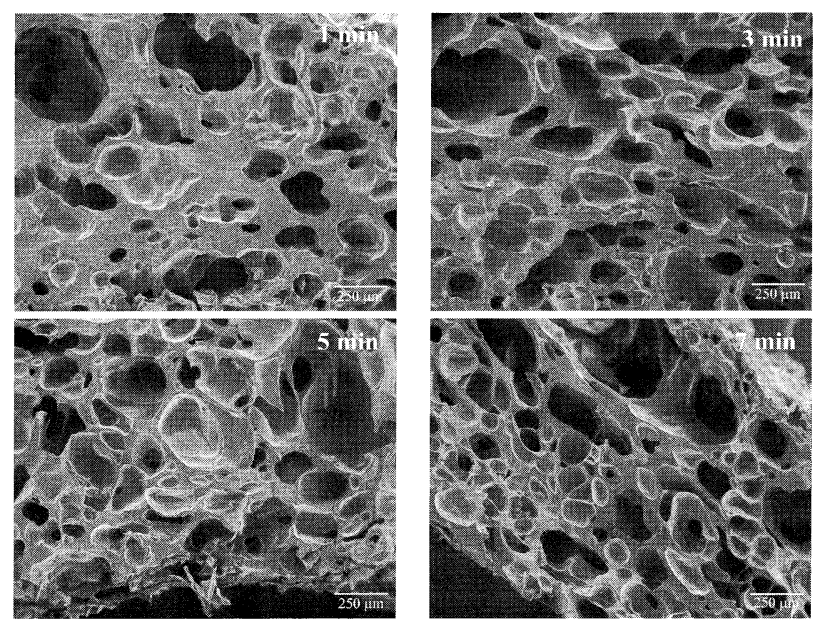

Fig. 3 SEM Photos of Fried Samples Containing 70\% Initial Moisture (x60).

り出すと試料は常温に戻り完全に両成分のガラス転移曲 線の下部に移行しクリスピーな多孔質の発達したガラス 状フライ様衣ができることになる。

Figs. 2 抢よび 3 は上述経過に伴う多孔質構造の SEM 写真像である。初期水分が $60 \%$ のバッター様試料の場 合，フライ開始 1 分ですでに細孔は大きく発達しその後 7 分までそのサイズは変化しないと見ることができる。 しかし $40 \%$ のドウ状試料の場合，1 分経過後から 5 分ま での間に細孔が若干大きく発達することがわかる。初期 水分 $40 \%$ 試料でデンプンの糊化が起こっていないこと から考えると，この発達に関与しているのはグルテンで あると考えられる。以上，状態図上にフライ調理過程を 描くことで，フライ調理の全体像が明らかにされたと思 われる。その結果，フライ調理の際に発達する多孔質構 造はドウのような水分の少ない材料の場合はデンプンの 糊化よりもグルテンのマトリックスの粘弾性の影響が大 きく，バッターのように水分の多い試料の場合にはデン 
プンの糊化とその粘性に影響されて決定されると考えら れる。

\section{3 油吸収と多孔質構造}

フライ調理過程における微細構造の発達は油吸収に直 接間接に影響する重要な因子である。フライ過程，ポス トフライ過程それぞれの過程における油吸収メカニズム は異なるが，どちらにも水分蒸発に伴う細孔の発達が影 響する。ここでは，フライ過程とポストフライ過程に分 けて解説する。

\section{$3 \cdot 1$ フライ過程における油吸収}

一般的に食材が油の中でフライされる際，水蒸気が多 孔質微細構造を形成し，周囲の油がその細孔を通って食 材の内部に侵入する。具体的には，フライ調理食品のフ ライ過程での油吸収は初期水分含量，および形成される 多孔質構造の状態によって左右される。初期水分含量の 異なる小麦粉一水混合モデル食品のフライ過程における 吸収油量と残存水分量の変化を追跡した結果を Fig. 4 に 示す ${ }^{12)}$ 。吸収された油量は所定の時間，熱油に浸漬した 後, 油から取り出しすばやく表面に付着した油を除去し た後，試料内に残った油を定量した值である。同図に は，油から取り出した後，すなわちポストフライ過程に おけるデー夕も示してある。すべての試料においてフラ イ時間の進行とともに吸収油量の上昇がみられる。その $40,60,70 \%$ の初期水分含量を持つ試料の油吸収率は試料
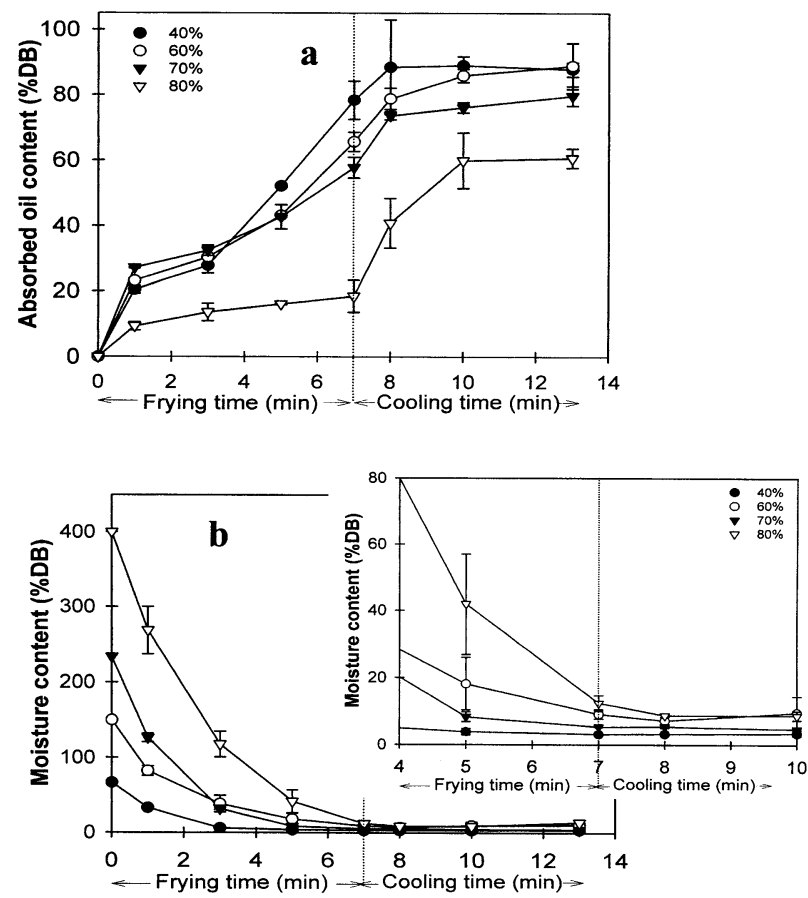

Fig. 4 The Changes of (a) Absorbed Oil and (b) Moisture Content for Wheat Flour-Water Mixture Containing 40-80\% Moisture during Frying and Cooling Process.
間には大きな差は見られなかったが，いずれも $80 \%$ 初 期水分試料より油吸収がかなり高い值を示した。フライ 後，油から取り出されると急に油吸収率が上昇する傾向 があり，その後の冷却ポストフライ期間でなお経過時間 とともに油の吸収が起こっていることがわかる，すなわ ち，先に述べたようにフライ調理での油吸収は油に浸漬 しているフライ過程，取り出した後のポストフライ過程 の両過程で起こることがこの図から明らかである。水分 含量についてはフライ過程初期 $3 \mathrm{~min}$ の間に急速に減少 を示し，フライ過程 $7 \mathrm{~min}$ 後では比較すれば $80 \%$ の初期 水分含量試料の残存水分がやや高いものの，その他の初 期水分含量の試料はドライベースで $10 \%$ 以下となり有 意な差は見られなかった。

ポテトチップのフライ過程における油吸収と水分減少 を調べた研究では同様の結果が得られており, 油吸収, 水分減少ともフライ時間の $1 / 2$ 乗に比例することが報告 されている ${ }^{13)}$ 。小麦粉一水混合系モデルに対してもフラ イ時間の $1 / 2$ 乗に対してプロットを試みたところ Fig. 5 に示すように，初期水分 $80 \%$ の試料の油吸収は低く推 移しながらフライ時間の $1 / 2$ に対して直線関係を示して いた ${ }^{12)}$ 。一方， $80 \%$ 以外の初期水分含量の試料のプロッ トはいずれも同一曲線上に重なっていた。また，水分含
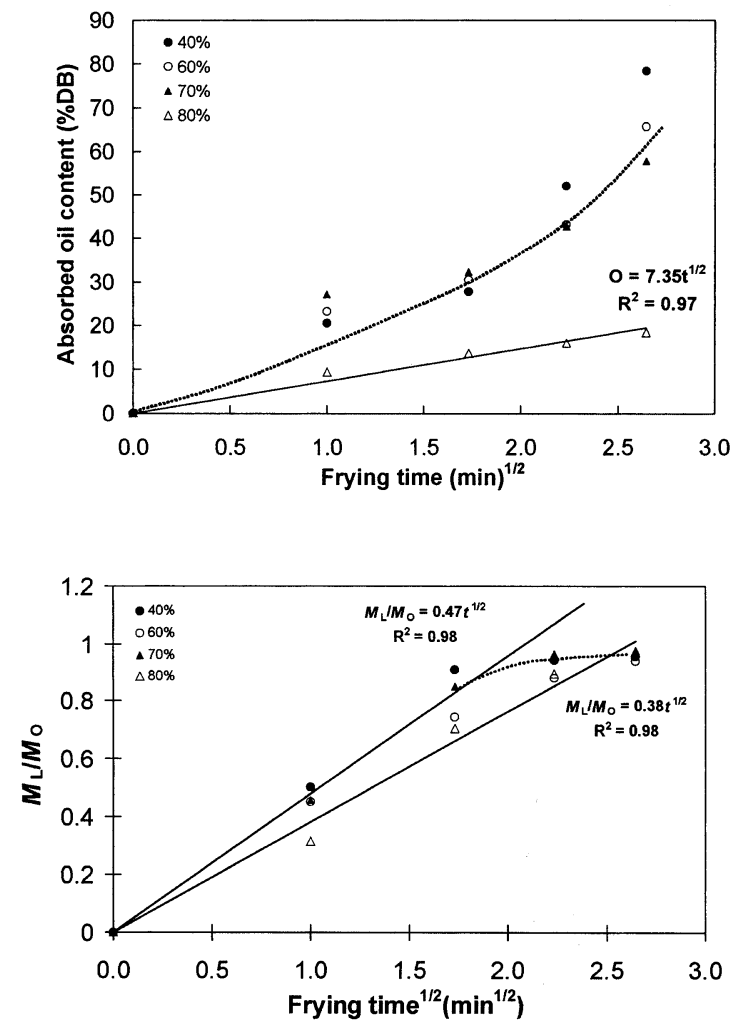

Fig. 5 Relationship between Fraction of a) Absorbed Oil and b) Moisture Loss and the Square Root of Frying Time for the Samples with Initial Moisture Content of $40-80 \%$. 
量の変化に対しては規格した水分量で示すと 0.8 までは, すべての試料でフライ時間の $1 / 2$ に比例して水分が変化 していた。すなわち水分の減少速度に関しては初期水分 含量の影響は大きくなく，およその範囲で一致してい た。

もとより，初期水分含量の相違はデンプンの糊化の程 度に影響を及ぼし，多孔質発達を制御し最終的に油吸収 に影響を及ぼす。Fig. 6 にフライ 7 分後の試料の多孔質 構造を示すが， 40 〜 70\%の初期水分含量の試料では多 少の差は見られるが，いずれも多孔質構造を持ってい た。これに対して $80 \%$ 初期水分含量試料では孔が極端 に少なく観察された。これは 40 〜 70\%の試料では細孔 が SEM で観察した解像度の 100 ミクロン程度であった のに対して，80\%試料では見た目にも巨大な孔，数ミリ 以上に発達した孔となったためSEM 状ではフラットな 面と観察されたためと考えられる。また，80\%試料の場 合，フライ過程における温度上昇によってデンプンの完 全に近い糊化が起こったためデンプン自体が水分を多量 に吸収し蒸発量が抑えられたと考えられる。この結果推 論はFig. 5 の蒸発速度の推移からも支持される。また渡 辺 $^{14)}$ らは, 近年ドウやマクロなデンプン一水混合系の加 熱による糊化の際には局所的糊化が生じデンプンがより 水分を吸収しやすくなる部位ができ，そこに水分濃度勾 配逆らって水分が吸収される現象があることを示してい る。 $80 \%$ 初期水分含量試料の場合類似の現象が起き, 水 分の蒸発が抑制されたものと考えられる。またさらに, 糊化したデンプンは，表面でフィルム状となり水分の蒸 発を妨げる作用もあると考えられる。こういったフライ 過程に打ける水分蒸発減少速度は水分の固体内拡散律速

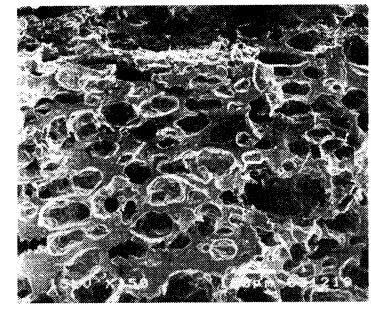

$40 \%$

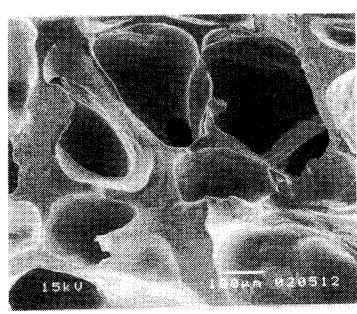

$70 \%$

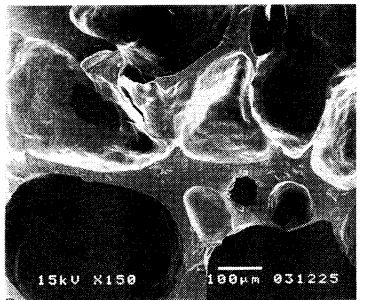

$60 \%$

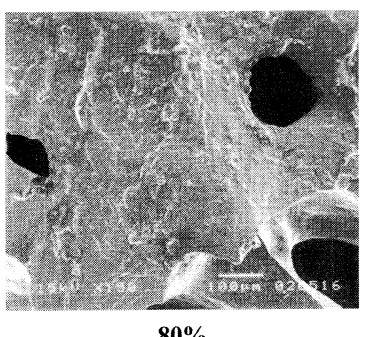

$80 \%$
Fig. 6 SEM Photos of Cross-Section Wheat Flour Models Prepared with Different Initial Moisture Content at 7 min of Frying.
であると考えられてきた ${ }^{15)}$ 。その場合，試料の細孔構造 が影響を与える。すなわち細孔率や細孔のサイズの増大 とともに水分拡散は上昇する ${ }^{16)}$ 。 Marousis と Saravacos ${ }^{17)}$ はフライによる乾燥中孔のチャンネルの発達が有効水分 拡散率を増大させ内部から表面への水分移動を助長する モデルを提唱したが，Fig. 6 に示すSEM 像のように初 期水分含量によって多孔質構造にかなりの相違が見られ るにもかかわらず, Fig. 5 で先に述べたように水分蒸発 速度は殆ど初期水分含量に影響されない, すなわち多孔 質構造に影響されない結果となっていた。すなわち，フ ライ過程における水分蒸発は水分拡散律速ではなく, 蒸 発のためか，デンプン糊化のための熱拡散律速であると 考えられる。

以上のようなフライ過程中の水分の蒸発による多孔質 の発達は油の吸収されるスペースを作ることになるが， 水分蒸発速度の大きい間は必ずしも油は食品中に侵入し ない。Fig. 7 にはライ過程における水分減少速度と油 吸収速度の関係を示す ${ }^{12)}$ 。 $40 \sim 70 \%$ の初期水分含量を もつ試料の場合, フライ過程での油吸収速度は水分蒸発 速度と逆比例関係にあることがわかる。すなわち，こ れら試料ではフライ初期に水分が激しく蒸発している間 は油の吸収は極めて少なく, 水分がある程度蒸発し蒸発 速度が低下してくると急激に油の吸収が増加することが わかる。一方, $80 \%$ の初期水分含量試料では水分減少速 度の広い範囲で油吸収速度と直線関係を示し, その関係 は他の水分含量試料と逆の関係を示していた。すなわち $80 \%$ 水分含量試料のフライ過程では水分蒸発速度が減少 しても，なお油吸収速度は上昇しない結果が得られた。 これはすでに示した Fig. 4 や Fig. 5 の結果と一致する。 この原因は SEM 像で観察されたように $80 \%$ 試料では極 めて孔の数が少ないことによるものであると考えられ る。ただし，80\%試料の場合，極めて大きな孔となって いることも観察された。

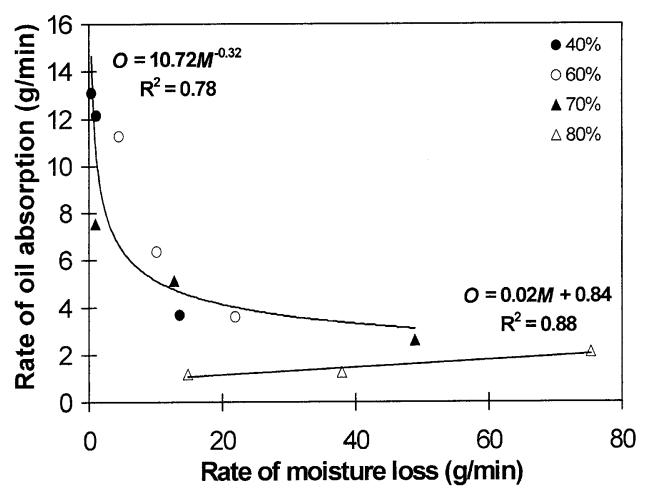

Fig. 7 Correlation between Rate of Moisture Loss and Oil Absorption for the Samples with Initial Moisture Content of 40-80\%. 


\section{$3 \cdot 2$ ポストフライ過程における油吸収}

ポストフライ過程は，とくにフライ調理全体のなか で, 油吸収の主要な過程となっている。食品がフライ ヤーから取り出されると, 多孔質内の蒸気は温度降下と ともに凝縮する。これは, 食品内の多孔質内部に真空を 作り出すことになる。この間に食品表面から落ちなかっ た油は減圧により多孔質内に強制的に吸引されると考え られる。このプロセスを考慮すると，表面に付着した油 が少ないほど最終的な油吸収率は低くなると考えられ る。さらに一歩踏み込むと，油の表面付着量は表面の凹 凸構造，表面に露出した多孔質構造によって大きく影響 されると推察される。一般的に，フライ調理品の不規則 な表面凹凸構造はフライ過程で形成され，その表面凹凸 がポストフライ過程における油吸収に影響を及ぼす。

筆者らは，このフライ調理品の表面凹凸は初期水分含 量によって変化しポストフライ過程の油吸収に影響を及 ぼすことを実験的に調べた ${ }^{18)}$ 。その研究の中で表面の不 規則度をフラクタル解析により調べ凹凸の程度をフラク タル次元で評価することを試みた。フラクタル次元と は，線状の形態について 1 から 2 の範囲をとり，その線 が直線的または滑らかな場合は 1 に近い值をとり，複雑 に入り組んだ海岸線のような形態であると 2 に近い値を 示す。Fig. 8 には小麦粉一水混合モデル食品をフライし た後の試料断面を観察し表面部の凹凸不規則度をフラク タル画像解析を行った結果を示す。初期水分含量により 表面構造が大きく変化し，フラクタル次元が変わること が明らかになった。すなわち，フライ過程では初期水分 が少ないドウのような試料では表面は滑らかで（フラク タル次元も低い), 水分含量が多くなると表面構造は複

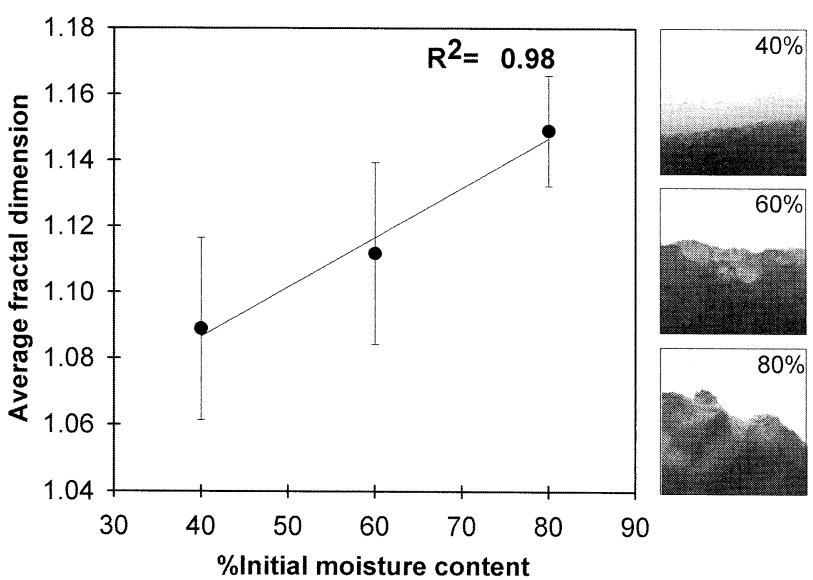

Fig. 8 The Relationship between Initial Moisture Content of the Samples Fried at $150^{\circ} \mathrm{C}$ for $5 \mathrm{~min}$ and the Average Fractal Dimension.

Each average fractal dimension was calculated from twenty data. The error bars: the standard deviation \pm $0.027, \pm 0.027$, and \pm 0.016 for $40 \%, 60 \%$, and $80 \%$ sample, respectively.

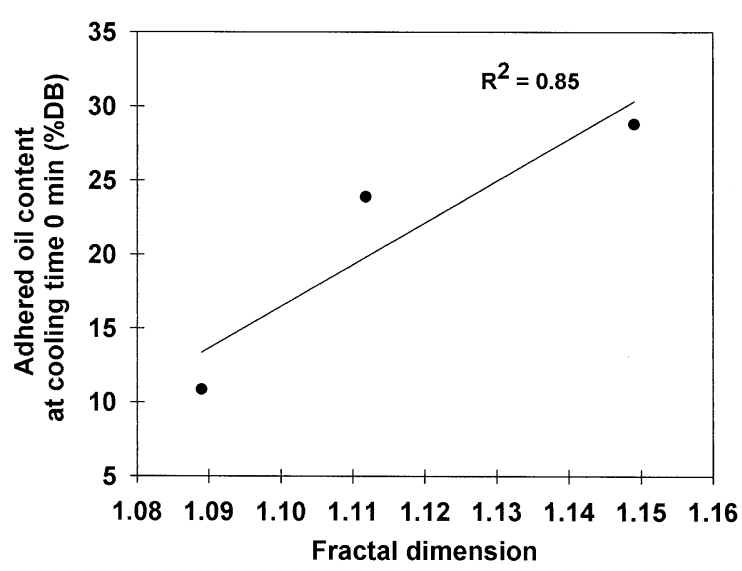

Fig. 9 The Relationship between the Adhered Oil at the Initial Cooling Time ( 0 min of cooling) of the Sample Fried at $150^{\circ} \mathrm{C}$ for $5 \mathrm{~min}$ and Average Fractal Dimension.

雑な入り組んだ構造をとるようになる（フラクタル次元 が大きい)。細孔体積は表面構造と密接に関連するが, $80 \%$ 試料の場合, 非常に大きな孔が発達し, 表面の凹凸 を作っている。Fig 9 は，また，表面に付着した油量 （油から取り上げた直後の試料の）と平均的表面フラク タル次元との関係を示したものである。明らかに表面の 構造が複雑なほど付着した油量が多いことがわかる。

ポストフライ過程では, 油から試料を取り出した直 後, すなわちポストフライ過程初期において急速な油の 吸収が見られるが，次第に吸収は収まる。Fig. 4aを見 ると, 表面形態が複雑で表面付着油が多い初期水分含量 80\%の試料が最もポストフライ過程で油吸収度が高い。 Aguilera と Gloria-Hernandez ${ }^{19)}$ による類似の報告があ

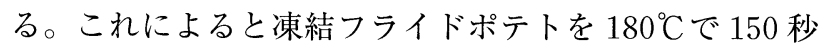
間フライし室温に冷却すると試料温度は $100^{\circ} \mathrm{C}$ 以上から

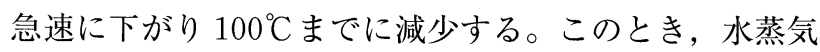
の凝縮が起き激しい減圧が起こり油の吸収が起こるが, その後 $100^{\circ} \mathrm{C}$ 以下に試料温度が降下すると大気圧と多孔 内の圧力差は小さくなり油の吸収は緩やかになるとされ る。しかし試料内温度が $100^{\circ} \mathrm{C}$ を超えてさらに高温にな ることに疑問が残る。また Kawas と Moreira ${ }^{8)}$ が先に も述べたトルティージャチップスの油吸収はフライ過程 よりもその後のクーリング過程, すなわちポストフライ 過程でより多く起こると結論付けている。ただ，その結 果は定量性にそしく完全な結論とはいえない。筆者等の 見解では初期水分が 40 から 60\%のドウに近い食品では 油の吸収は主としてフライ過程で起こり, 初期水分含量 が $80 \%$ といったバッターのような食品では逆に油の吸 収はポストフライ過程で主として起こると結論できる。 


\section{4 まとめ}

フライ調理過程における油吸収のドライビングフォー スは 2 つの作用による。すなわち油吸収はフライ過程で は蒸気圧に拮抗する小さな細孔内の毛管力による吸収に より起こり, ポストフライ過程では蒸気の凝縮減圧によ る吸収によって生じる。また初期水分含量の低い食品へ の油吸収は主としてフライ過程での油吸収が支配的であ り, 水分含量の高いバッター状の食品ではポストフライ 過程での表面付着油の吸収が支配的であることが明らか にされた。さらに，初期水分含量の高いバッター様の試 料ではフライ過程における大きなスケールの多孔質が発 達し表面の凹凸が大きくなる。このことによって表面に 付着する油量も多くなり，ポストフライ過程で大きな油 吸収をもたらすことが明らかにされた。

以上，かなり荒削りの議論ではあるが，こういった食 品素材の物理化学的変化は多孔質構造発達に影響を及ぼ し，さらには油の吸収と密接に関わっていることが少な からず見えてきたものと考えられる。

\section{文献}

1) D. Dana \& I.S. Saguy, Food Sci. Technol. Res., 7, 265-79 (2001).

2) I.S. Saguy, G. Ufheil \& S. Livings, Ocl-Oleagineux Corps Gras Lipides, 5, 30-5 (1998).

3) L. Slade \& H. Levine, Crit. Rev. Food Sci. Nutr., 30, 115-360 (1991).

4) L. Slade \& H. Levine, The glassy state phenomenon in food molecules in The Glassy State in Foods (J.M.V. Blanshard \& P.J. Lillford ed.) Nottingham Univ. Press, Nottingham, 35-101 (1993).

5) C.I. Moraru \& J.L. Kokini, Compr. Rev. Food Sci. Food Safety, 2, 120-38 (2003).

6）鈴木 徹，日本食品工学会誌，8,47-58 (2007).

7) O. Vitrac, G. Trystram \& A.L. Raoult-Wack, Eur. J. Lipid Sci. Technol., 102, 529-38 (2000).

8) M.L. Kawas \& R.G. Moreira, J. Food Sci., 66, 300-6 (2001).

9) P. Thanatuksorn, K. Kajiwara \& T. Suzuki, J. Sci. Food Agric., 87, 2648-59 (2007).

10) G. Kaletunc \& K.J. Breslauer, J. Thermal Anal., 47, 1267-88 (1996).

11) M.T. Kalichevsky \& J.M.V. Blanshard, Carbohydrate Polymers, 19, 271-278 (1992).

12) Jpn.J.Food Engin., 6, 49-55 (2005).

13) M.H. Gamble, P. Rice \& J.D. Selman, Int. J. Food Sci. Technol., 22, 233-41 (1987).

14) H. Watanabe, M. Fukuoka, A. Tomiya \& T. Mihori, J. Food Engin., 49, 1-6 (2001).

15) P. Rice \& M.H. Gamble, Int. J. Food Sci. Technol., 24, 183-187 (1989).

16) J.F. Velez-Ruiz, F.T. Vergara-Balderas, M.E. SosaMorales \& J. Xique-Hernandez, Int. J. Food Prop., 5, 127-44 (2002).

17) S.N. Marousis \& G.D. Saravacos, J. Food Sci., 55, 1367-70, 1372 (1990).

18) P. Thanatuksorn, T. Suzuki, P. Jantawat \& C. Pradist suwana, J. Sci. Food Agric., 85, 2574-80 (2005).

19) J.M. Aguilera \& H. Gloria-Hernandez, J. Food Sci., 65, $476-9(2000)$ 